\title{
Study of macro-fungi belonging to order Agaricales of Poonch District Azad Jammu and Kashmir (AJK)
}

\author{
Gull-e-Laala ${ }^{1}$, Muhammad Usman Raja ${ }^{1 *}$, Syed Riaz Ali Gardezi², \\ Gulshan Irshad ${ }^{1}$, Abida Akram ${ }^{3}$ and Imran Bodlah ${ }^{4}$ \\ 1. Department of Plant Pathology, PMAS-Arid Agriculture University Rawalpindi-Pakistan \\ 2. Department of Plant Pathology, University of Poonch Rawalakot-Pakistan \\ 3. Department of Botany, PMAS-Arid Agriculture University Rawalpindi-Pakistan \\ 4. Department of Entomology, PMAS-Arid Agriculture University Rawalpindi-Pakistan \\ *Corresponding author's email: usman2012@uaar.edu.pk
}

Citation

Gull-e-Laala, Muhammad Usman Raja, Syed Riaz Ali Gardezi, Gulshan Irshad, AbidaAkram and Imran Bodlah. Study of macro-fungi belonging to order Agaricales of Poonch District Azad Jammu and Kashmir (AJK). Pure and Applied Biology. Vol. 8, Issue 1, pp27-33. http://dx.doi.org/10.19045/bspab.2018.700160

\begin{tabular}{llll}
\hline \hline Received: 24/07/2018 & Revised: 26/09/2018 & Accepted: 30/09/2018 & Online First: 04/10/2018 \\
\hline
\end{tabular}

\section{Abstract}

The aim of present study was to explore rich, diversified but mostly unexplored myco-flora of Poonch district of Azad Jammu and Kashmir (AJK) for the presence of macro-fungi belonging to order Agaricales of class Basidiomycetes. The study period was spread over from May, 15 to Oct, 2015 with temperature ranges between $21-36^{\circ} \mathrm{C}$. A total of 16 species belonging to 11 genera and 8 families of order agaricales were collected and identified. Out of 16,5 were edible while remaining 11 were deadly poisonous species. Most of the species (14) were found growing on soil while Omphalotus olivascensand Pleurotus ostreatus were found on wood. Microscopic study revealed that maximum pileus size was $17 \mathrm{~cm}$ found in Chlorophyllum rhacodes while minimum pileus size $1.5 \mathrm{~cm}$ was recorded of Psilocybe cyanescens. Spore print of species was predominantly white, black and brown, however, pale spore print was found in Pleurotus ostreatus. Spore size also varies and maximum spore size was 14-8 $\times 12-9 \mu \mathrm{m}$ found in Panaeolus campanulatuswhile minimum spore size was 4.5-6×3-5 $\mu \mathrm{m}$ found in Agaricus placomyces. It is also pertinent to mention that many of agaricales members found during studies such as Pleurotus ostreatus has great medicinal, nutritional and commercial value. Conversely, Amanita phalloides commonly known as death cap was also found in same area. The results of this pilot study in existing and expanding area of mycology showed that there is great deal of potential is present which further needed to be explored and exploited.

Keywords: Agaricales; Amanita phalloides; Poonch; Pleurotus ostreatus

\section{Introduction}

Wild mushrooms are part of human trade, diet and medicine since centuries. Technology helped humans to cultivate few of species of these wild mushrooms to meet ever increasing demands but still many of wild mushrooms are not cultivable and only found in certain habitats on specific substrates and environment. Therefore, these are personally collected from particular habitat but absolute care is needed as many of these natural treasures are deadly poisonous. Mushrooms can grow in a diversified environment but temperate zones with thick 
forest and abundance of dead organic matter favors natural growth of mushrooms. Natural habitat plays pivotal role in mushrooms growth [1]. A major group of gilled mushrooms belongs to class Basidiomycetes. Mushrooms belonging to class Basidiomycetes have a macroscopic fruiting structure called basidium or basidiocarp that is either above the ground or may be below the ground. Basidiomycetes approximately contain 10,000 species of 550 genera and 80 families [2].

In Basidiomycetes, order Agaricales because of its distinctive gilled mushrooms is of paramout importance. The order has 33 extant families, 413 genera and over 13000 described species. Edible mushrooms of order Agaricales are important for improving human and environmental health. Pleurotus spp. of this order which also known as oyster mushroom holds great medicinal importance as it is rich in calcium, folic acid, zinc, vitamins especially vitamin $\mathrm{C}$ and $\mathrm{D}$, protein, fibre, iron, etc. It reduces cholesterol level and is an anti-cancer mushroom [3]. All edible mushrooms belonging to Pleurotaceae and Agaricaceae family are naturally gluten free, rich in vitamin $\mathrm{D}$, vitamin $\mathrm{B}$, protein, carbohydrates and minimize heavy weights [4]. Medicinal value of edible mushrooms belonging to class Basidiomycetes is also of great importance. These edible mushrooms are used for treatment of diseases like cancer, diabetes, heart attack and many more. In short, mushrooms have wide range of uses both as food and medicine.It is plausible to mention that few members of Agaricales order such as Amanita phalloides also called death cap is deadly poisonous mushroom. Similiarly, Mycena polygramma which contains deadly toxin muscarine is also member of order agaricales. Extreme care and expertise are needed during mushroom collection as the specimens are so confusing that people consider poisonous as edible species [5].
Forest account just $4.8 \%$ of the total area of Pakistan but provide $80 \%$ of livelihood of native communities [6]. Azad Jammu and Kashmir (AJK) lies 80kilometer North-East of capital Islamabad in foothills of southern Karakorum range. Current study was carried out in Poonch district of Azad Jammu and Kashmir. Poonch district comprises of three Tehsils which are; Rawalakot, Hajira and Abaspur. Total area of district Poonch is 330 square miles and total population recorded is 459,000 [7]. The cooler climate of Poonch district with short summers is an ideal climate for the growth of macro-fungi. There are sporadic reports about the presence of macrofungi of this region. The best season that is suitable for wild mushrooms growth in Poonch district (AJK) starts from Feburary to October. During this duration mushrooms are abundantly found in cold temperate areas but due non-conservation practices, quantity of wild mushrooms is decreasing. During same season in the North Western Himalayas, Lakhanpal and his associates recorded Agarics that belongs to 300 species of 59 genera and 15 families of order Agaricales [8, 9]. Therefore, the aim of the present study was to explore local myco-flora of district Poonch AJK as there was no systematic study to our knowledge in past was done about these macro delicacies of life. In consequence, most of the forest worth is wasted and not even consumed by local people. Therefore, a survey of native people and local markets of Poonch area was also conducted to gather all obligatory information about macro-fungi regarding its ethno-mycological uses. However, major focus was to collect these macro-fungi from their natural habitat and to identify them on the basis of their morphological features, microscopic studies and their medicinal and nutritional value.

\section{Materials and methods}

Mushrooms were collected randomly from different localities of Poonch District AJK during year 2015. Collection was carried out 
during May-Oct, 2015 as temperature during these months favors the growth of mushrooms. Wild mushrooms belonging to order Agaricales of class Basidiomycetes were found abundantly in Poonch district with temperature ranges between $21-32^{\circ} \mathrm{C}$. Macro-fungi samples were brought to laboratory of Plant Pathology University of Poonch and Department of Plant Pathology PirMehr Ali Shah, Arid Agriculture University Rawalpindi (PMAS-AAUR).

\section{Collection of agaricales from natural}

\section{habitat}

Mushrooms are very delicate entities therefore carefully removed with the help of trowel and spade. In field, these were putinto tissue papers, plastic bags, boxes. Specimen were always collected in a way that base remain intact as it was later used in identification. Deep rooted specimens were dug out with the help of trowel and spade while shallow based species were manually picked from the substrate [10]. On trunks and branches, specimen were collected with help of a sharp knife. Characters such as temperature, habitat, substrate, colourand growth habits were noted in field note book. Field photographs were taken in way that all visible sides of specimens with their substrates were covered.

\section{Macroscopic and microscopic characterization}

All the naked characters of specimen (size, colour, texture, pileus, lamellae and stipe) were noted in field [11]. Mushrooms specimens were compared with already published literature and keys [12]. Slides having drop of water or lactophenol were used microscopic studies. Mushroom spores were meticulously dusted on slides. In addition, $3 \% \mathrm{KOH}$, cotton blue and Mezler's reagent were also used during slide preparation. Ocular micrometer was used for the measurement of spore size. Published literature was considered while observing spore print.For spore print, pileus was cut to release spores on a white paper which was later carefully observed. In case no spore prints were released then the cutted pileus was left on white paper for another 24 hours $[10,12,13]$.

Dry and wet preservation

Wild mushrooms dried by putting them naturally in sunlight or in oven at temperature between $\quad 40-45^{\circ} \mathrm{C}$. After, complete dehydration, the specimens were wrapped in polythene bags and were sealed properly. Commercial formalin (5\%), iodine solution and 5\% $\mathrm{KOH}$ (Potassium hydroxide) and FAA (Formaldehyde acetic acid) were also used in wet preservation. Preserved mushrooms were kept in labeled jars in cool and dry place in laboratory.

\section{Results and discussion}

During present study 16 species belonging to 8 families and 11 genera of order Agaricales were collected and identified from Poonch District AJK during year 2015 (Table 1). Poonch valley is about 8500 hectares at an altitude of 2500 meters above sea level. Poonch area divided among Pakistan and India and part of Himalaya mountain range. Therefore, weather is predominantly temperate with thick forests which made this area an ideal niche for growth of macrofungi. Macro-fungi collected in a time span of 6 months (May-October) when temperature ranged between $21-32{ }^{\circ} \mathrm{C}$. It seemed that mild summer is best season for the collection mushroom as from north western Himalayas lies in Indian a number of Agaricales were also recorded [9]. It is plausible to mention that among 16 species, only two Pleurotus ostreatus and Omphalotus olivascenswere collected from wood while rest were present on soil (Figure 1). Other researchers also found these mushrooms on wood in Himalayas and other parts of world [14]. 
Table.1. List of macro-fungi belonging to agaricales order collected from Poonch district of Azad Jammu and Kashmir during year 2015

\begin{tabular}{|c|c|c|c|c|c|c|c|c|}
\hline Order & Family & Genus & Species & Vernacular & Location & Habitat & Month & Edibility \\
\hline Agaricales & Agaricaceae & Agaricus & arvensis & Horse Mushroom & Mutyalmera & Soil & August & Edible \\
\hline & & $A$ & placomyces & Flat topped & Darek & Soil & September & Poisonous \\
\hline & & $A$. & subrutilescens & Wine coloured & Deewan & Soil & August & Edible/ Irritant \\
\hline & & Chlorophyllum & rhacodes & Shaggy parasol & Deewan & Soil & May & Poisonous \\
\hline & Amanitaceae & Amanita & phalloides & Death cap & Dawarandi & Soil & September & Poisonous \\
\hline & & A. & vaginata & Grisette & Nakkar & Soil & September & Edible \\
\hline & Hymenogastraceae & Psilocybe & cyanescens & Oyster & Devigali & Soil & October & Poisonous \\
\hline & Marasmiaceae & Omphalotus & olivascens & Shiny cap & Kharick & Wood & October & Poisonous \\
\hline & Mycenaceae & Mycena & polygramma & Orange mat coprinus & Tора & Soil & August & Poisonous \\
\hline & Pleurotaceae & Pleurotus & ostreatus & Bell shaped mottle gill & Banjonsa & Wood & August & Edible \\
\hline & Psathyrellaceae & Coprinellus & Micaceus & Glockend & Tarnoti & Soil & September & Edible \\
\hline & & $C$ & radians & Groyyed Bonnet & Phagwati & Soil & June & Poisonous \\
\hline & & Panaeolus & campanulatus & Jack-o-lantern & Hurnamera & Soil & July & Poisonous \\
\hline & & $P$. & rickenni & Wavy caps & Phagwati & Soil & October & Poisonous \\
\hline & Tricholomataceae & Clitocybe & Gibba & Funnel Mushroom & Khaigala & Soil & September & Edible \\
\hline & & Collybia & Acervata & Gymnopusacervatus & KotMatty Khan & Soil & October & Poisonous \\
\hline
\end{tabular}
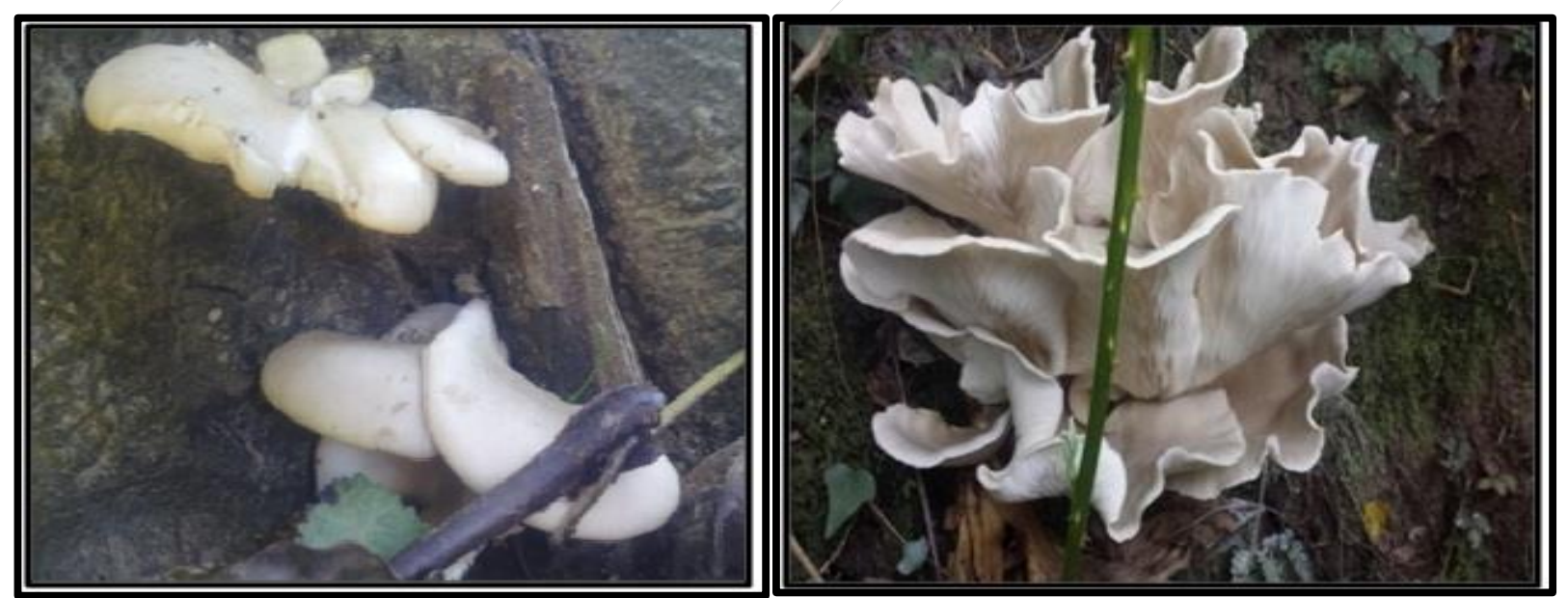

Figure 1.Members of order Agaricales growing on wood. a. Pleurotus ostreatus b. Omphalotus olivascens 
Out of 16, only 5 were edible while rests were considered as poisonous according to standard literature on mushroom. Agaricus arvensis, Amanita vaginata, Clitocybe gibba, Coprinellus micaceus, Pleurotus ostreatus were listed as edible mushroom. While Agaricus subrutilescens was considered as choice edible specie with a pleasant almond odor but it is better to avoid eating it as it can cause severe gastric disorders [15]. It is interesting fact that we found edible and poisonous species not only within same family but also with in genus such as in family Agaricaceae and genus Agaricus. A. arvenis is edible but other two members of same genus $A$. placomyces and $A$. subrutilescens were poisonous. Similarly, genus Amanita, a member of family Amanitaceae had both edible species ( $A$. vaginata) and deadly poisonous (A. phalloides) as well (Table $1 \&$ Figure 2). This mushroom is commonly known as death cap [16].

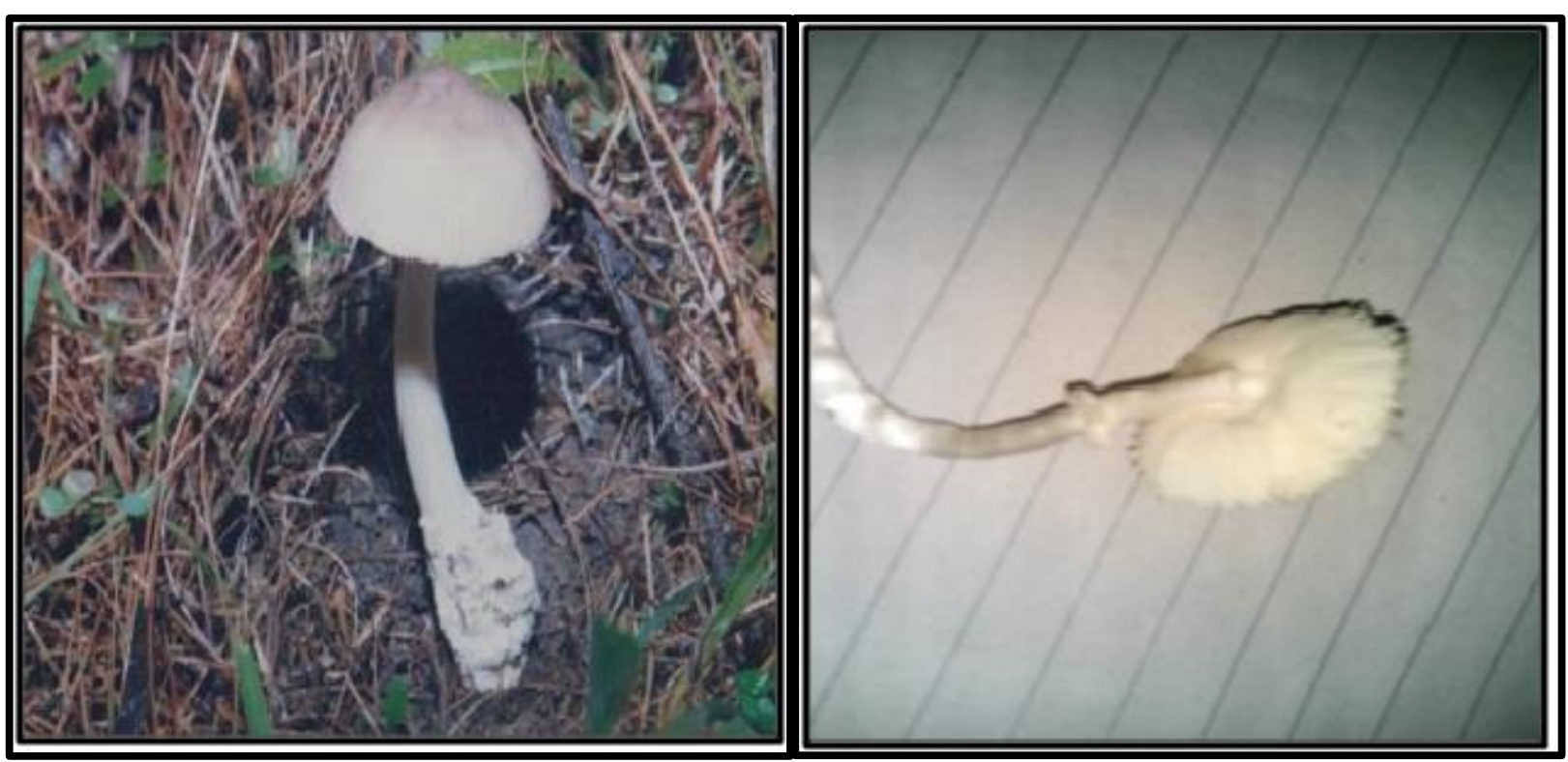

Figure 2.Amanita spp. collected from Poonch district. a)Amanita phalloides (death cap)b. Amanita vaginata (edible)

It is extremely poisonous and causes acute liver failure as it contains powerful hepatotoxins [16]. It has also been reported by [17] that Amanita muscaria, Amanita phalloides and other poisonous mushrooms caused deaths in Syrian refugees in Germany and Sweden who mistakenly considered these mushrooms as edible. During present studies it was also found that natives in Poonch district had no scientific reason to eat or reject mushroom and only relied knowledge of forefathers. It can end into a life threatening situation as in present study a poisonous mushroom (Mycena polygramma)
(Figure 3) was also found which contains deadly toxin muscarine in it.

Microscopic study revealed that maximum pileus size was $17 \mathrm{~cm}$ found in Chlorophyllum rhacodes while minimum pileus size $1.5 \mathrm{~cm}$ was recorded in Psilocybe cyanescens. Spore print of species was predominantly white, black and brown, however, pale spore print was found in Pleurotus ostreatus. Spore size also varies and maximum spore size was 14-8 $\times 12-9 \mu \mathrm{m}$ found in Panaeolus campanulatus while minimum spore size was 4.5-6× 3-5 $\mu \mathrm{m}$ found in Agaricus placomyces (Table2). 
Results of present study showed abundance of maco-fungi belonging to order agaricales of class Basidiomycetes in Poonch district of AJK which usually overlooked due to remoteness. However, if this natural treasureis properly explored and marketed it will not only improve our knowledge about fungal biodiversity of area but also help to alleviate poverty of these areas by selling taxonomically important species.

Table 2. Characterization of macro-fungi of order agaricales collected from Poonch District of Azad Jammu and Kashmir during year 2015

\begin{tabular}{|c|c|c|c|c|c|}
\hline Scientific Name & Common Name & $\begin{array}{c}\text { Pileus/Fruiting } \\
\text { body }\end{array}$ & Stipe & $\begin{array}{c}\text { Spore } \\
\text { print }\end{array}$ & Spore size \\
\hline Agaricusarvensis & Horse mushroom & $7-9 \mathrm{~cm}$ & $6-8 \mathrm{~cm}$ & Brown & $8-4 \times 6-5 \mu \mathrm{m}$ \\
\hline Agaricusplacomyces & Flat topped mushroom & $9-13 \mathrm{~cm}$ & $9 \mathrm{~cm}$ & Brown & $4.5-6 \times 3-5 \mu \mathrm{m}$ \\
\hline Agaricussubrutilascens & Wine colouredagaricus & $7-9 \mathrm{~cm}$ & $8-11 \mathrm{~cm}$ & Brown & $6-5 \times 4.5-3 \mu \mathrm{m}$ \\
\hline Chlorophyllumrhacodes & Shaggy parasol & $5-17 \mathrm{~cm}$ & $6-9 \mathrm{~cm}$ & Brown & $7-11 \times 6-10 \mu \mathrm{m}$ \\
\hline Amanita phalloides & Death cap & $5-12 \mathrm{~cm}$ & $10-13 \mathrm{~cm}$ & White & $9-8 \times 11-7 \mu \mathrm{m}$ \\
\hline Amanita vaginata & Grisette & $2-3.5 \mathrm{~cm}$ & $7-9 \mathrm{~cm}$ & White & $7-13 \times 4-6.5 \mu \mathrm{m}$ \\
\hline Pleurotusostreatus & Oyster mushroom & $5-12 \mathrm{~cm}$ & $2 \mathrm{~cm}$ & Pale & $8-12.5 \times 3.5-5 \mu \mathrm{m}$ \\
\hline Coprinellusmicaceus & Shiny cap & $2-4 \mathrm{~cm}$ & $2-10 \mathrm{~cm}$ & Black & $8-10 \times 6.5-4 \mu \mathrm{m}$ \\
\hline Coprinellus radians & Orange mat coprinus & $2-2.5 \mathrm{~cm}$ & $4-7 \mathrm{~cm}$ & White & $10-5 \times 9-3 \mu \mathrm{m}$ \\
\hline Panaeoluscampanulatus & Bell shaped mottle gill & $2-3.5 \mathrm{~cm}$ & $6-9 \mathrm{~cm}$ & Black & $14-8 \times 12-9 \mu \mathrm{m}$ \\
\hline Panaeolusrickenni & Glockend & $3-5 \mathrm{~cm}$ & $13-16 \mathrm{~cm}$ & Black & $13-15 \times 9.5-11 \mu \mathrm{m}$ \\
\hline Mycenapolygramma & Grovved bonnet & $2-4 \mathrm{~cm}$ & $7-11 \mathrm{~cm}$ & White & $9-11 \times 7.5-5 \mu \mathrm{m}$ \\
\hline Omphalotusolivascens & Jack-o'-lantern mushroom & $5-9 \mathrm{~cm}$ & $3-7 \mathrm{~cm}$ & White & $7-8 \times 3-5 \mu \mathrm{m}$ \\
\hline Psilocybecyanescens & Wavy caps & $1.5-3.5 \mathrm{~cm}$ & $2-5 \mathrm{~cm}$ & Brown & $6-11 \times 4-7 \mu \mathrm{m}$ \\
\hline Clitocybegibba & Funnel mushroom & $4-9 \mathrm{~cm}$ & $6-7.5 \mathrm{~cm}$ & White & $8-5 \times 9-3 \mu \mathrm{m}$ \\
\hline Collybiaacervata & Gymnopusacervatus & $3-4.5 \mathrm{~cm}$ & $5-11 \mathrm{~cm}$ & White & $11-13 \times 7-10 \mu \mathrm{m}$ \\
\hline
\end{tabular}

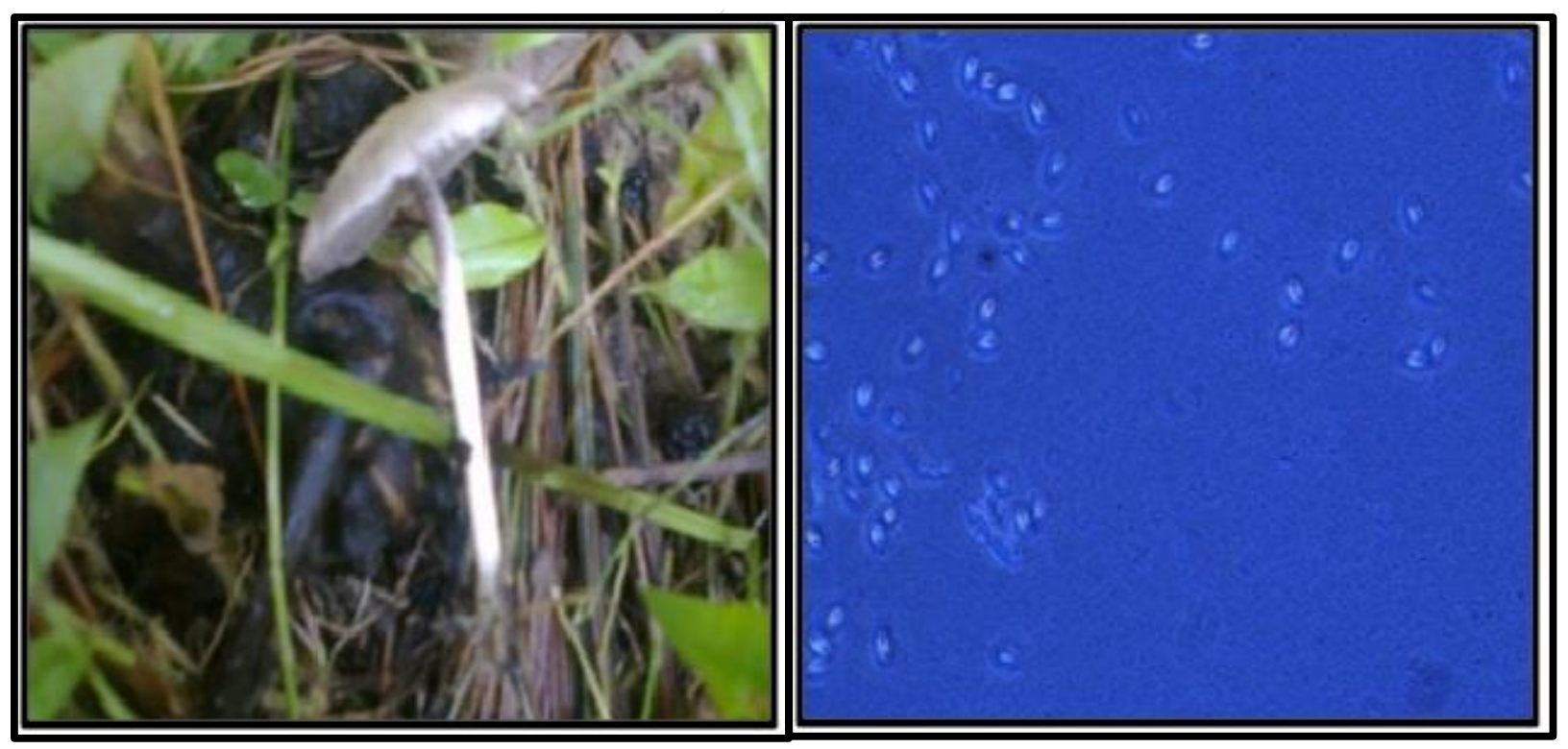

Figure 3. a. Mycena polygramma growing on dead organic matter present on soil. b. White spore print of Mycena polygramma

\section{Conclusion}

It is concluded that Poonch district is rich with macro-fungi and some of them important both economically as well medicinally. There is dire need that these species must be conserved in their natural 
habitats. Proper collection, preservation and marketing could also be helpful for native inhabitants of these areas to earn extra money.

\section{Authors' contributions}

Conceived and designed the experiments: M Usman \& S Riaz, Performed the experiments: GE Laala, Analyzed the data: GE Laala, M Usman \& G Irshad, Contributed materials/ analysis/ tools: M Usman, S Riaz, G Irshad, A Akram \& I Bodlah, Wrote the paper: M Usman \& GE Laala.

\section{References}

1. Susmitha S, Ranganayaki P, Vidyamol K K \& Vijayaraghavan R (2013). Purificationand characterization of Catalase enzyme from Agaricusbisporus. Int J Curr Microbiol App Sci 2(12): 255-263.

2. Dudka LA \& Wasser SP (1987). Reference book of a mycologists and mushroomers. Kiey. Nauk. Dumka, pp 536.

3. Hobbs C (1995). Medicinal mushrooms: an exploration of tradition, healing and culture. Botanica Press, Santa Cruz, California.

4. Rop O, Mlcek J \& Jurikova T (2009). Beta glucans in higher fungi and their health effects. Nutr Rev 67: 624-631.

5. Knudsen H \& Vesterhout (2008). Funga Nordica. Copenhagen. Nordsvamp. pp 321.

6. Latif A, Shinwari $\mathrm{ZK} \&$ Begum S (2005). Potential and market status of mushrooms as Non-Timber forest products in Pakistan. Ethnobotan Leaflets 1-5.

7. GOAJK (2015). Official website of the
Government of Azad Kashmir http://www.ajk.gov.pk

8. Gardezi RA \& Ayub N (2000). Mushrooms of Kashmir. Pak J Phytopath 14(8):23-31.

9. Lakhanpal TN (2010). Biology of Indian Morels. IK International Publ. New Delhi, pp 286.

10. Pala SA, Wani AH, Boda, RH \& Mir RA (2012). Three hitherto unreported macrofungi from Kashmir. Himalaya. Pak J Bot 44(6): 2111-2115.

11. Atri NS, Kaur A \& Kaur H (2003).Wild mushrooms collection and identification. Mushroom Res 14: 56-59.

12. Arora D (1986). Mushrooms demystified: A comprehensive guide to the fleshy fungi. $2^{\text {nd }}$ Edition Ten Speed Press, Berkley, California, USA pp 976.

13. Kuo M (2001). Making spore prints. Retrieved from the Mushroom Expert.com:http://www.bluewillopages. com/mushroomexpert/herbarium.html.

14. Malik AR, Wani AH, Bhat MY \& Parveen S (2017.Enthnomycological knowledge of some wild mushrooms of northern districts of Jammu and Kashmir, India. Asian J Pharm Clin Res 10(9):399-405.

15. Michael WB (2000). Introduction to Mushrooms.The Evergreen State College, Olympia Washington.

16. Santi L, Magioli C, Mastroroberto M, Tufoni M, Napoli L \& Caraceni P (2012). Acute liver failure caused by Amanita phalloides poisoning.Int $J$ of Hepatol 1- 6.

17. Al Rifai F (2015). Poisonous mushroom kills Syrian migrants. https://en.zamanalwsl.net/index.php. 